\title{
CORNEAL EPITHELIAL AND STROMAL CHANGES AFTER MYOPIC PHOTOREFRACTIVE KERATECTOMY
}

\author{
Radwan, Y.(*), Abozaid M., Al Samman A. \& Abdellatif, I. \\ Ophthalmology dept., Faculty of Medicine, Sohag Univ., Sohag, Egypt \\ *E-mail: radwany727@gmail.com
}

\begin{abstract}
Purpose: to evaluate the corneal epithelial and stromal Changes after myopic photorefractive keratectomy (PRK) Patient and methods: The study was established in Sohag Refractive Center, Sohag, Egypt, from October 2017 till November 2018. It included 50 eyes of 28 patients with age range from 20 to 40 years old who subjected to PRK for the correction of myopia or compound myopic astigmatism. AS-OCT (Avanti - Optovue Taiwan) and corneal topography using Sirius Scheimpflug Placido topography (CSO, Florence, Italy) were done for all eyes pre and post-myopic photorefractive keratectomy (PRK). Results: The study was conducted on 50 eyes of 28 patients, 6 were operated on uniocular. 24 eyes were for females (48 \%) and 26 eyes were for males (52\%) with their mean age $28.12 \pm 6.22$. the study showed a generalized pattern of decreased epithelial thickness in the period of the $1^{\text {st }}$ month after performing PRK with significant $P$ value for repeated measures over 6 months for all parts of the cornea except for the superior part which was not statistically significant. As regards the stromal thickness, the study showed a generalized pattern of decrease of the stromal thickness among the 6 months period after performing PRK. Conclusion: Epithelial thickness showed a decrease of thickness mainly in the central part except the superior part which was relatively the thickest. As regards the stromal thickness, all corneal showed significant change of stromal thickness after 1 month of PRK except the central part
\end{abstract}

Keywords: Photorefractive Keratectomy, Corneal epithelial changes, Corneal stromal changes.

\section{Introduction}

Conventional or customized photo ablative techniques used to modify the optical power of the cornea achieve their effect by altering the anterior corneal surface contour [1]. The corneal epithelium is a moldable [2] and active corneal layer that maintains the optical quality of the eye by remodeling itself to compensate for any changes in the stromal surface shape, e.g., those induced by keratorefractive surgery [3]. Knowledge of the preoperative corneal epithelial and stromal thickness profiles and their respective changes after corneal refractive surgery may contribute to a better understanding of the outcomes [4]. Mapping of the corneal epithelium has been attempted using various technologies, including immersion techniques such as high frequency ultrasound biomicroscopy, very high frequency digital ultrasound [5-8] and confocal microscopy [9]. OCT has been developed for non-invasive cross-sectional 
imaging in biological systems by using low-coherence interferometry to produce a two-dimensional image of optical scattering from internal tissue microstructures in a way that is similar to ultrasonic pulse-

\section{Patients and Methods}

This study was prospective interventional which established in Sohag Refractive Center, Sohag, Egypt, from October 2017 till November 2018. The study included 50 eyes of 28 patients with age range from 20 to 40 years old who subjected to

\subsection{Inclusion criteria}

*) Patients of myopia or compound myopic astigmatism with spherical equivalent refraction equal or less than 6.00D. *) Patients age between 20:40 ys. *) Patients not candidate for Lasik due to thin cornea

\subsection{Exclusion criteria}

*) Patients of myopia or compound myopic astigmatism with their spherical equivalent refraction >-6.00D. *) Patients age between less than 20 or more than 40 ys. *) Patients with suspect corneas in

\subsection{Preoperative evaluation}

Full ophthalmological examination was done for all patients and included: 1) Uncorrected distance visual acuity (UDVA). 2) Subjective manifest refraction. 3) Corrected distance visual acuity (CDVA). 4)

\subsection{Operative procedures}

Preparation for the surgery included application of prophylactic topical antibiotic eye drops (Gatifloxacin $0.3 \% 5$ times per day) in the 24 hours preoperatively followed by topical anaesthesia (Benoxinate hydrochloride $0.4 \%$ applied 2 minutes before surgery). After application of povidone iodine $10 \%$ surgical scrub on the lashes and eyelids, a closed-loop lid speculum was applied. In all eyes, treatment consisted of Phototherapeutic keratectomy (PTK) performed using an excimer laser (VISX S4IR) for removal of the epithelium to a depth of $50 \mu \mathrm{m}$ and then ablation by excimer laser as the correction treatment. After laser ablation, MMC $0.02 \%$ was app- echo imaging [10]. The aim of our work is to evaluate the corneal epithelial and stromal Changes after myopic photorefractive keratectomy (PRK)

PRK for the correction of myopia or compound myopic astigmatism. Written informed consent was obtained before surgery from all patients.

(calculation of a residual stromal bed less than 300 um after subtracting the sum of the planned laser in situ). *) Patients with normal corneal topography.

corneal topography. *) Patients with general systemic diseases such as diabetes or collagen diseases. *) Hazy cornea which can mask the result.

Slit lamp examination. 5) AS-OCT (Avanti Optovue Taiwan). 6) Corneal topography using Sirius Scheimpflug Placido topography (CSO, Florence, Italy). 7) Fundus examination.

lied for 20 seconds in all cases. A silicone hydrogel bandage contact lens will be applied after laser ablation until complete epithelial healing confirmed. The postoperative medications included topical antibiotic eye drops (Gatifloxacin 0.3\% 5 times daily for 1 week), topical steroid eye drops (prednisolone acetate 1\% 5 times daily for 1 week), lubricant eye drops, and systemic non-steroidal anti-inflammatory drugs. UV protection and $1000 \mathrm{mg}$ of vitamin $\mathrm{C}$ were prescribed for at least 1 month postoperatively with gradual tapering of topical steroids to decrease the risk of corneal scarring. 


\subsection{Postoperative Evaluation}

Postoperative visits was scheduled for the first postoperative day, and then at 1 week and 1, 3, 6, months after surgery. Full ophthalmological examination was done for all patients and included: 1) Uncorrected distance visual acuity (UDVA). 2)

\subsection{Statistical Analysis}

Data was analyzed using SPSS version 16. Quantitative data was represented as mean, standard deviation, median and range. Data was analyzed using. Comparison was made between preoperative and postoperative follow up data at 1,3 , and 6 months using RMANOVA test. Sphericity were

\section{Results}

The study was conducted on 50 eyes of 28 patients, 6 were operated on uniocular. 24 eyes were for females $(48 \%)$ and 26 eyes were for males (52\%) with their mean age $28.12 \pm 6.22$. Epithelial thickness of the studied patients was obtained using Anterior segment OCT (Avanti - Optovue Taiwan) and the mean corneal epithelial thickness pre-operatively showed no significant differences between thickness in each part. Stromal thickness of the studied patients was obtained by subtracting the full corneal thickness from the epithelial thickness at each part of the cornea measured by the Anterior segment OCT and the mean corneal stromal thickness pre-operatively. As regards epithelial thickness, It was noticed adecrease of thickness in central part compared to other parts while the superior part was relatively the thickest. Postoperatively, the study showed a generalized pattern of decreased epithelial thickness in the period of the $1^{\text {st }}$ month after performing PRK with significant $P$ value for repeated measures over 6 months for all parts of the cornea except for the superior part which was not statistically significant. In the period from the $1^{\text {st }}$ month postoperative and the $6^{\text {th }}$ month, a generalized pattern of re-increase of the epithelial thickness was observed as shown in fig. (1)
Subjective manifest refraction. 3) Corrected distance visual acuity (CDVA). 4) Slit lamp examination. 5) AS-OCT (Avanti-Optovue Taiwan). 6) Corneal topography using Sirius Scheimpflug Placido topography (CSO, Florence, Italy).

examined using Mauchly's Test of Sphericity. Bonferroni post hoc test to examine the difference at each time point. Graphs were produced by using Excel or STATA program $\mathrm{P}$ value was considered significant if it was less than 0.05

tab. (1). In addition, tab. (2) illustrated the positive correlation between epithelial thickness at 6 months postoperatively and preoperative epithelial thickness in all parts of the cornea. The study showed that the central cornea had the highest significant increase in thickness over time with correlation coefficient value of 0.73 , while the superior part showed the least with correlation coefficient value of 0.05 . As regards the stromal thickness, The study showed a generalized pattern of decrease of the stromal thickness among the 6 months period after performing PRK, as shown in fig. (2), with significant $P$ value for repeated measures for all parts of the cornea except the nasal part which showed a $\mathrm{P}$ value $=0.001$ (statistically not significant). Unlike epithelial thickness, all parts of the cornea showed statistical significant change of stromal thickness after 1 month from performing PRK except the central part. At both 3rd and 6th month, only the central and superior part of the cornea showed significant change when compared preoperatively as shown in tab. (3). The study showed that the inferior cornea had the highest significant change in stromal thickness over time with correlation coefficient value of 0.7 , while similar to epithelial thickness, the superior part of the cornea showed the least change with correlation coefficient value of 0.3 as 
shown in tab. (4). As regards complications, there was only one case of post PRK haze, the patient was prescribed topical steroids and lubricants and no improvement and DALK was recommended for the patient, fig. (3)

Figure (1) A statistical diagram shows changes in epithelial thickness over 6 months.

Table (1) Epithelial thickness of studied patients over time

\begin{tabular}{|c|c|c|c|c|c|c|}
\hline $\begin{array}{l}\text { Epithelial } \\
\text { Thickness }\end{array}$ & Preoperative & $1^{\text {st }}$ month & $3^{\text {rd }}$ month & $6^{\text {th }}$ month & $\begin{array}{l}\text { Change } \\
\text { (Post at 6 }^{\text {th }} \\
\text { month-pre) }\end{array}$ & $\begin{array}{c}\mathbf{P} \\
\text { value }\end{array}$ \\
\hline $\begin{array}{l}\text { Central } \\
\text { Mean } \pm \text { SD } \\
\text { Median (range) }\end{array}$ & $\begin{array}{c}55.32 \pm 5.28 \\
54(48: 68) \\
\end{array}$ & $\begin{array}{c}53.96 \pm 5.69 \\
55(43: 66) \\
\end{array}$ & $\begin{array}{c}59.16 \pm 8.20 \\
57(46: 82) \\
\end{array}$ & $\begin{array}{c}61.12 \pm 7.77 \\
58(48: 82)\end{array}$ & $\begin{array}{l}5.8 \pm 5.2 \\
4(0: 21) \\
\end{array}$ & $<0.0001$ \\
\hline \multicolumn{7}{|c|}{$\mathrm{P} 1=0.32, \mathrm{P} 2<0.0001, \mathrm{P} 3<0.0001, \mathrm{P} 4<0.0001, \mathrm{P} 5<0.0001, \mathrm{P} 6<0.0001$} \\
\hline $\begin{array}{l}\text { Superior } \\
\text { Mean } \pm \text { SD } \\
\text { Median (range) }\end{array}$ & $\begin{array}{c}55.58 \pm 9.56 \\
53(41: 94) \\
\end{array}$ & $\begin{array}{c}52.84 \pm 6.19 \\
52(40: 68)\end{array}$ & $\begin{array}{c}56.48 \pm 5.52 \\
56(48: 69) \\
\end{array}$ & $\begin{array}{c}57.86 \pm 6.21 \\
57(50: 70) \\
\end{array}$ & $\begin{array}{c}2.28 \pm 11.12 \\
3(-43: 23) \\
\end{array}$ & 0.005 \\
\hline \multicolumn{7}{|c|}{$\mathrm{P} 1=0.39, \mathrm{P} 2=1.00, \mathrm{P} 3=0.92, \mathrm{P} 4<0.0001, \mathrm{P} 5<0.0001, \mathrm{P} 6=0.10$} \\
\hline $\begin{array}{l}\text { Inferior } \\
\text { Mean } \pm \text { SD } \\
\text { Median (range) }\end{array}$ & $\begin{array}{c}56.28 \pm 6.02 \\
56(45: 71)\end{array}$ & $\begin{array}{c}55.74 \pm 4.53 \\
55(49: 49)\end{array}$ & $\begin{array}{l}59.56 \pm 6.22 \\
58.5(52: 78)\end{array}$ & $\begin{array}{l}60.6 \pm 5.54 \\
59(55: 77)\end{array}$ & $\begin{array}{c}4.32 \pm 4.87 \\
3(-3: 13)\end{array}$ & $<0.0001$ \\
\hline \multicolumn{7}{|c|}{$\mathrm{P} 1=1.00, \mathrm{P} 2=0.003, \mathrm{P} 3<0.0001, \mathrm{P} 4<0.0001, \mathrm{P} 5<0.0001, \mathrm{P} 6=0.12$} \\
\hline $\begin{array}{l}\text { Temporal } \\
\text { Mean } \pm \text { SD } \\
\text { Median (range) }\end{array}$ & $\begin{array}{c}54.02 \pm 5.18 \\
54(45: 67)\end{array}$ & $\begin{array}{l}51.9 \pm 6.59 \\
53(39: 64)\end{array}$ & $\begin{array}{l}56.8 \pm 7.51 \\
56(45: 76)\end{array}$ & $\begin{array}{c}59.56 \pm 7.02 \\
59(49: 77)\end{array}$ & $\begin{array}{c}5.54 \pm 5.80 \\
4(-4: 24)\end{array}$ & $<0.0001$ \\
\hline \multicolumn{7}{|c|}{$\mathrm{P} 1=0.19, \mathrm{P} 2=0.01, \mathrm{P} 3<0.0001, \mathrm{P} 4<0.0001, \mathrm{P} 5<0.0001, \mathrm{P} 6<0.0001$} \\
\hline $\begin{array}{l}\text { Nasal } \\
\text { Mean } \pm \text { SD } \\
\text { Median (range) }\end{array}$ & $\begin{array}{l}54.9 \pm 5.21 \\
54(46: 68)\end{array}$ & $\begin{array}{c}54.74 \pm 6.12 \\
56(42: 66)\end{array}$ & $\begin{array}{c}58.52 \pm 6.82 \\
58(49: 82)\end{array}$ & $\begin{array}{c}59.74 \pm 7.25 \\
58(50: 82)\end{array}$ & $\begin{array}{c}4.84 \pm 6.91 \\
4(-8: 18)\end{array}$ & $<0.0001$ \\
\hline
\end{tabular}

$\boldsymbol{P}$ value for repeated measures; $\boldsymbol{P 1}$ compared preoperative \& $1^{\text {st }}$ month; $\boldsymbol{P} 2$ preoperative \& $3^{\text {rd }}$ months; $\boldsymbol{P} 3$ preoperative \& $6^{\text {th }}$ months; $\boldsymbol{P 4} 1^{\text {st }}$ month \& $3^{\text {rd }}$ month; P5 $1^{\text {st }}$ month \& $6^{\text {th }}$ month and P6 $3^{\text {rd }}$ month $\& 6^{\text {th }}$ month.

Table (2) Correlation between epithelial thickness at 6 months postoperatively and preoperative epithelial thickness in all parts of the cornea

\begin{tabular}{|l|r|c|}
\hline $\begin{array}{c}\text { Correlation between epithelial thickness at 6 months postoperatively } \\
\text { and preoperative epithelial thickness }\end{array}$ & $\begin{array}{c}\text { Correlation } \\
\text { coefficient }\end{array}$ & $\begin{array}{c}\text { P } \\
\text { value }\end{array}$ \\
\hline Central & 0.73 & $<0.0001$ \\
\hline Superior & 0.05 & 0.72 \\
\hline Inferior & 0.65 & $<0.0001$ \\
\hline Temporal & 0.58 & $<0.0001$ \\
\hline Nasal & 0.42 & 0.002 \\
\hline
\end{tabular}




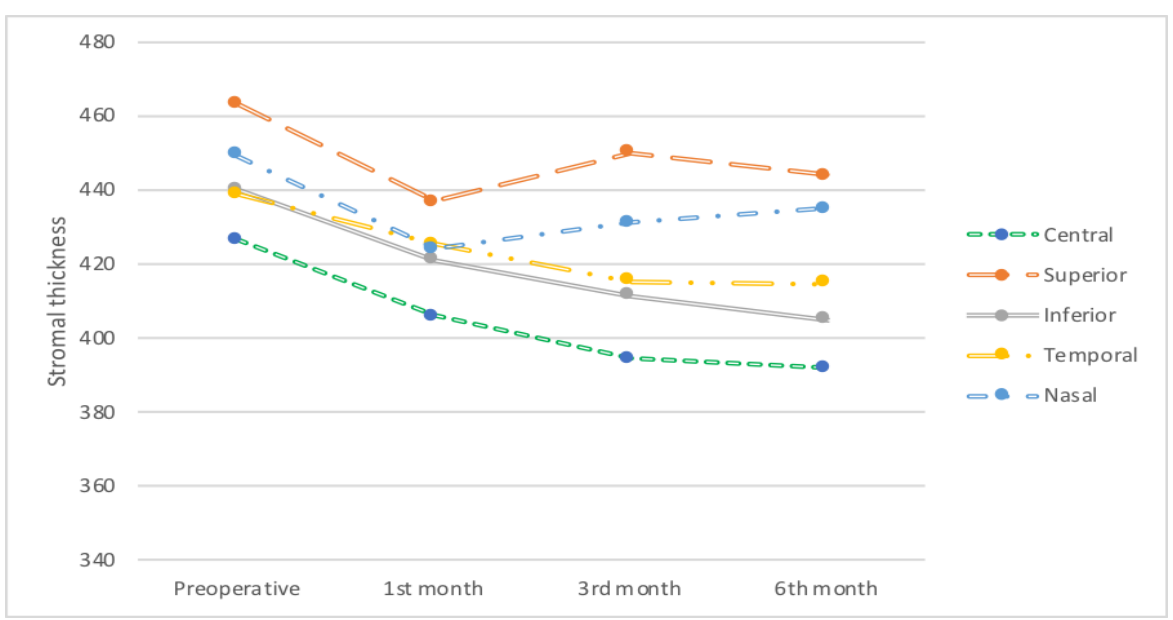

Figure (2) A statistical diagram shows changes in stromal thickness over 6 months.

Table (3) Stromal thickness of studied patients over time

\begin{tabular}{|c|c|c|c|c|c|c|}
\hline $\begin{array}{l}\text { Stromal } \\
\text { thickness }\end{array}$ & Preoperative & $1^{\text {st }}$ month & $3^{\text {rd }}$ month & $6^{\text {th }}$ month & $\begin{array}{l}\text { Change } \\
\text { (Post at } 6^{\text {th }} \\
\text { month-pre) }\end{array}$ & Pvalue \\
\hline $\begin{array}{l}\text { Central } \\
\text { Mean } \pm \text { SD } \\
\text { Median (range) }\end{array}$ & $\begin{array}{l}426.42 \pm 38.66 \\
426(314: 498)\end{array}$ & $\begin{array}{l}405.88 \pm 55.70 \\
395(333: 577)\end{array}$ & $\begin{array}{l}394.24 \pm 35.03 \\
406(330: 463)\end{array}$ & $\begin{array}{l}391.88 \pm 36.17 \\
405(325: 456)\end{array}$ & $\begin{array}{l}-34.54 \pm 40.34 \\
-26.5(-169: 36)\end{array}$ & $<0.0001$ \\
\hline \multicolumn{7}{|c|}{$\mathrm{P} 1=0.11, \mathrm{P} 2<0.0001, \mathrm{P} 3<0.0001, \mathrm{P} 4=0.48, \mathrm{P} 5=0.24, \mathrm{P} 6=0.005$} \\
\hline $\begin{array}{l}\text { Superior } \\
\text { Mean } \pm \text { SD } \\
\text { Median (range) }\end{array}$ & $\begin{array}{l}463.14 \pm 20.20 \\
460(431: 508)\end{array}$ & $\begin{array}{l}436.86 \pm 42.33 \\
439(356: 522)\end{array}$ & $\begin{array}{l}449.92 \pm 33.28 \\
454(390: 531)\end{array}$ & $\begin{array}{l}443.74 \pm 34.99 \\
454(380: 510)\end{array}$ & $\begin{array}{l}-19.4 \pm 34.74 \\
-24(-92: 34)\end{array}$ & $<0.0001$ \\
\hline \multicolumn{7}{|c|}{$\mathrm{P} 1<0.0001, \mathrm{P} 2=0.04, \mathrm{P} 3=0.002, \mathrm{P} 4=0.19, \mathrm{P} 5=1.00, \mathrm{P} 6=0.003$} \\
\hline $\begin{array}{l}\text { Inferior } \\
\text { Mean }=\text { SD } \\
\text { Median (range) }\end{array}$ & $\begin{array}{l}440=24.94 \\
433.5(409: 484)\end{array}$ & $\begin{array}{l}421=39.73 \\
412.5(351: 484)\end{array}$ & $\begin{array}{l}411.44 \pm 33.92 \\
411(349: 471)\end{array}$ & $\begin{array}{l}405 \pm 33.98 \\
409(345: 466)\end{array}$ & $\begin{array}{l}-35 \pm 24.23 \\
-35.5(-71: 20)\end{array}$ & $<0.0001$ \\
\hline \multicolumn{7}{|c|}{$\mathrm{P} 1<0.0001, \mathrm{P} 2<0.0001, \mathrm{P} 3<0.0001, \mathrm{P} 4=0.01, \mathrm{P} 5=0.001, \mathrm{P} 6=0.30$} \\
\hline $\begin{array}{l}\text { Temporal } \\
\text { Mean } \pm \text { SD } \\
\text { Median (range) }\end{array}$ & $\begin{array}{l}438.64 \pm 22.22 \\
429(415: 487)\end{array}$ & $\begin{array}{l}425.06 \pm 37.48 \\
413(360: 481)\end{array}$ & $\begin{array}{l}415.24 \pm 35.20 \\
414(354: 490)\end{array}$ & $\begin{array}{l}414.46 \pm 34.46 \\
415(364: 481)\end{array}$ & $\begin{array}{l}-24.18 \pm 30.68 \\
-21.5(-82: 55)\end{array}$ & $<0.0001$ \\
\hline \multicolumn{7}{|c|}{$\mathrm{P} 1=0.008, \mathrm{P} 2<0.0001, \mathrm{P} 3<0.0001, \mathrm{P} 4=0.46, \mathrm{P} 5=0.27, \mathrm{P} 6=1.00$} \\
\hline $\begin{array}{l}\text { Nasal } \\
\text { Mean } \pm \text { SD } \\
\text { Median (range) }\end{array}$ & $\begin{array}{l}449.2 \pm 22.46 \\
448(413: 488)\end{array}$ & $\begin{array}{l}423.86 \pm 35.37 \\
419(362: 484)\end{array}$ & $\begin{array}{l}431.12 \pm 41.94 \\
435(322: 492)\end{array}$ & $\begin{array}{l}434.76 \pm 44.68 \\
426(366: 555)\end{array}$ & $\begin{array}{l}-14.44 \pm 41.42 \\
-19.5(-84: 115)\end{array}$ & 0.001 \\
\hline \multicolumn{7}{|c|}{$\mathrm{P} 1<0.0001, \mathrm{P} 2=0.01, \mathrm{P} 3=0.10, \mathrm{P} 4=1.00, \mathrm{P} 5=0.71, \mathrm{P} 6=1.00$} \\
\hline
\end{tabular}

Table (4) Correlation between stromal thickening at 6 months postoperatively and preoperative stromal thickness in all parts of the cornea.

\begin{tabular}{|l|c|c|}
\hline $\begin{array}{r}\text { Correlation between stromal thickening at 6 months postoperatively } \\
\text { and preoperative stromal thickness }\end{array}$ & $\begin{array}{c}\text { Correlation } \\
\text { co efficient }\end{array}$ \\
\hline Central P value \\
\hline Superior & 0.42 & 0.002 \\
\hline Inferior & 0.30 & 0.03 \\
\hline Temporal & 0.70 & $<0.0001$ \\
\hline Nasal & 0.48 & 0.0004 \\
\hline
\end{tabular}




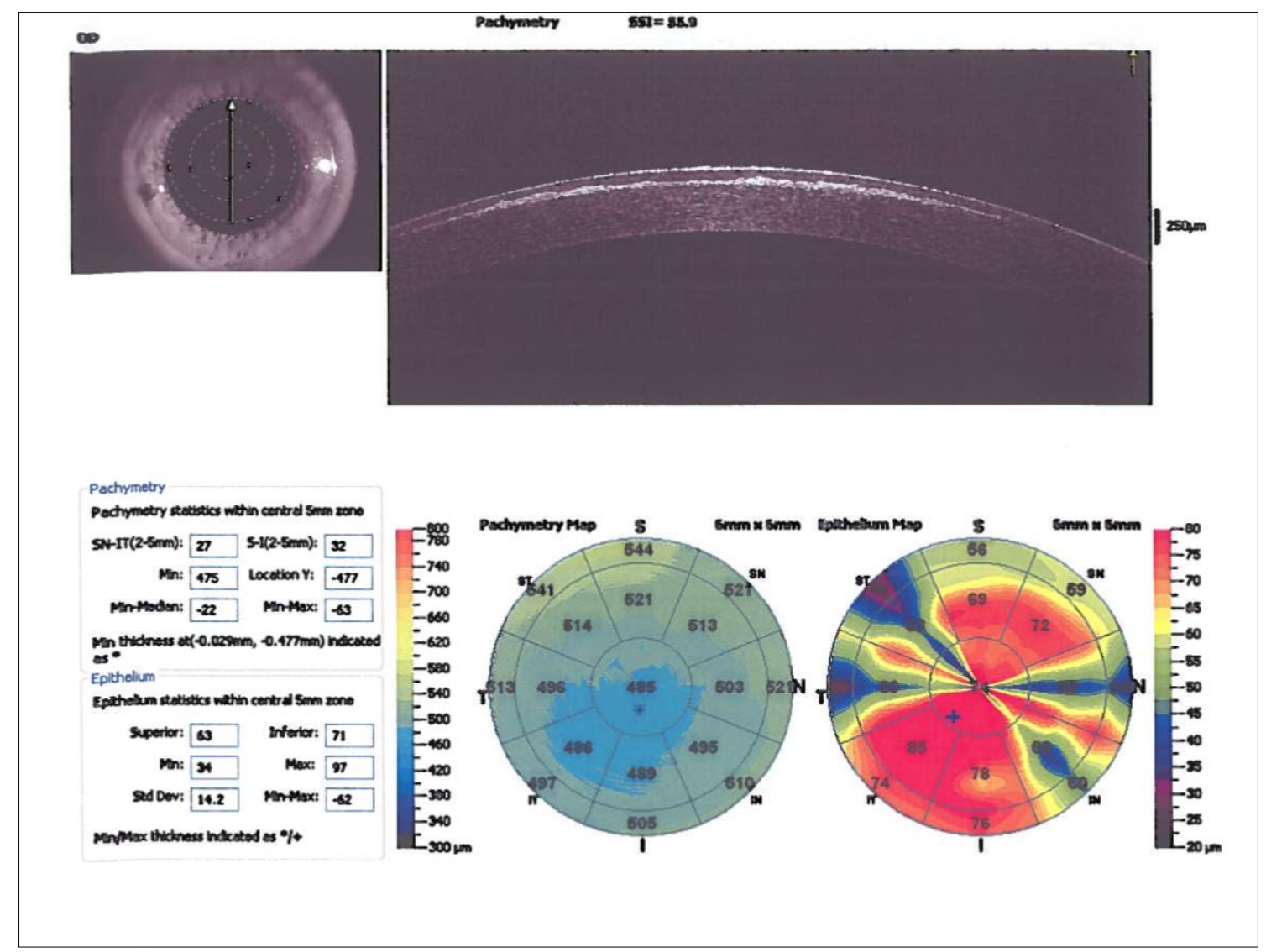

Figure (3) Postoperative anterior segment OCT (epithelial and corneal thickness) of right eye shows post PRK haze

\section{Discussion}

The corneal epithelium plays an important role in maintaining corneal transparency, keeps the integrity of the optical quality and protects the eye [11]. It is highly reactive to irregularities of the underlying stromal surface and has a rapid cell turnover [5]. In this study we aimed at detecting the corneal epithelial and stromal thickness changes after performing photorefractive keratectomy using spectral domain OCT technology. Several methods had been used to measure the epithelial thickness such as confocal microscopy that was used by Patel [12], Li [9], Erie [13]. They reported central epithelial thicknesses of 41-50.6 $\mu \mathrm{m}$ in normal corneas, which excluded the pre-corneal tear film thickness unlike our study. Their results were thinner than the central epithelial thickness of $55.32 \pm 5.2 \mu \mathrm{m}$ in normal eyes that we obtained. Very-high frequency ultrasound was another tool used for measurement of epithelial thickness by Reinstein et al. [7]. Their study excluded also the tear film and the central epithelial thickness of normal eyes was $53.4 \pm 4.6 \mu \mathrm{m}$. Their research also showed that corneal epithelium was thicker inferiorly than superiorly in the normal corneas. Our observation (S-I mean difference $=-0.96 \mu \mathrm{m}$ ) agreed with their results. Haque [14], Sin [15], Feng [16] and their colleagues used time-domain OCT systems to measure corneal epithelial thickness. They reported central corneal epithelial thicknesses of 52-54.7 $\mu \mathrm{m}$ in normal eyes, values that are close to our measurements. While, Wang et al., reported a thicker value, $59.9 \pm 5.9 \mu \mathrm{m}$ using the same instrument. Tao el al [17], Chen et al. [18], Kanellopoulos [19] and Asimellis [20] used the same measurement instrument as the one used in the current study. Tao 
et al, reported central corneal thickness of $52.5 \pm 2.4 \mu \mathrm{m}$. Chen et al, reported central corneal thickness of $54.79 \pm 3.71$ $\mu \mathrm{m}$ which is very similar to our results. Significant statistical difference between central and paracentral epithelial thickness was not detected in our study in which maximum difference between paracentral (temporal part) and central corneal thickness is $(0.96 \pm 0.8 \mu \mathrm{m})$. This result differed from the measurements with Artemis very highfrequency ultrasound which demonstrated $2.3 \mu \mathrm{m}$ thinner epithelium centrally than paracentrally (annulus between 3 and 3.4 $\mathrm{mm}$ ) [20]. The difference of $0.75 \pm 2.5$ $\mu \mathrm{m}$ between superior and inferior paracentral epithelium in the current study is considerably smaller than $1.7 \pm 2.1 \mu \mathrm{m}$, as reported by Chen et al. [18] who used the same measurement tool of our study. Also our results are smaller than $1.67 \pm 2.07 \mu \mathrm{m}$, as reported by Hou et al. [21] and smaller than $1.6 \pm 0.1 \mu \mathrm{m}$, as reported by $\mathrm{Li}$ et al. [9], both used fourier domain OCT. On the other hand our results were much more different than 5.3 to $5.9 \mu \mathrm{m}$ as reported by Reinstein et al. [7] who used Artemis very high frequency ultrasound in measurement. The variations of results may be caused by the patients' demographics and differences in instrumentation and the measurement technique (non-contact SD-OCT vs saline immersion ultrasound). In this study, the mean central stromal thickness $(426.42 \pm 38)$ was different from the results of Chen et al and their colleagues [18] $(492.24 \pm 29.03)$ who used the same measurement tool of our study and Moilanen et al [22], (476 \pm 25 um ) who used confocal microscopy to measure stromal thickness and Gatinel et al. [1], (482.05 \pm 30.89 ) who used orbscan with reported stromal thickness thicker than our results

\section{Conclusion}

Epithelial thickness showed a decrease of thickness mainly in the central part except the superior part which was relatively the thickest, followed by re-increase during the 6 months period. As regards the stromal thickness, a generalized pattern of decrease was observed among the 6 months period, all corneal showed significant change of stromal thickness after 1 month of PRK except the central part.

\section{References}

1. Gatinel D., Racine L., Hoang-Xuan T. Contribution of the corneal epithelium to anterior corneal topography in patients having myopic photorefractive keratectomy. J Cataract Refract Surg. 2007; 33 (11): 1860-1865.

2. Lian Y., Shen M., Jiang J., et al. Vertical and horizontal thickness profiles of the corneal epithelium and Bowman's layer after orthokeratology. Invest OphthaImol Vis Sci. 2013; 54: 691-696.

3. Schmoll T., Unterhuber A., Kolbitsch C. Precise thickness measurements of Bowman's layer, epithelium, and tear film. Optometry and Vision Science. 2012; 89: E795-802.

4. Chen X, Stojanovic A, Liu Y, et al. Postoperative changes in corneal epithelial and stromal thickness profiles after photorefractive keratectomy in treatment of myopia. J Refract Surg. 2015; 31 (7): 446-453.

5. Reinstein D., Archer T., Gobbe M. Corneal epithelial thickness profile in the diagnosis of keratoconus. J. of Refractive Surgery. 2009; 25: 604-610.

6. Reinstein D., Gobbe M., Archer T., et al. Epithelial, stromal, and total corneal thickness in keratoconus: Three-dimensional display with artemis very-high frequency digital ultrasound. J Refract Surg. 2010; 26: 259-271.

7. Reinstein D. Archer T., Gobbe M., et al. Epithelial thickness in the normal cornea: Three-dimensional display with Artemis very high-frequency digital ultrasound. J. of Refractive Surgery. 2008; 24: 571581 . 
8. Reinstein D., Gobbe M., Archer T., et al. Epithelial thickness profile as a method to evaluate the effectiveness of collagen cross-linking treatment after corneal ectasia. J Refract Surg. 2011; 27: 356-363.

9. Li H., Petroll W., Moller-Pedersen T. Epithelial and corneal thickness measurements by in vivo confocal microscopy through focusing (CMTF). Current Eye Research. 1997; 16: 214-221.

10. Huang D. Swanson E., Lin C. Optical coherence tomography. Science. 1991; 254: 1178-1181.

11. Zagon I., Sassani J., Ruth T., et al. Epithelial adhesion complexes and organ culture of the human cornea. Brain Res. 2001; 900: 205-213.

12. Patel S., Erie J., McLaren J., et al. Confocal microscopy changes in epithelial and stromal thickness up to 7 years after LASIK and photorefractive keratectomy for myopia. J Refract Surg. 2007; 23 (4): 385-92.

13. Erie J., Patel S., McLaren J., et al. Effect of myopic laser in situ keratomileusis on epithelial and stromal thickness: A confocal microscopy study. Ophthalmology. 2002; 109 (8): 1447-1452.

14. Haque S., Simpson T., Jones L. Corneal and epithelial thickness in keratoconus: A comparison of ultrasonic pachymetry, Orbscan II, and optical coherence tomography. J Refract Surg. 2006; 22:486-493

15. Sin S., Simpson T. The repeatability of corneal and corneal epithelial thickness measurements using optical coherence tomography. Optom Vis Sci. 2006; 83 (6): 360-365.
16. Feng Y., Simpson T. Corneal, limbal, and conjunctival epithelial thickness from optical coherence tomography. Optom Vis Sci. 2008; 85 (9): E880- E883.

17. Tao A., Wang J., Chen Q., et al. Topographic thickness of Bowman's layer determined by ultra-high resolution spectral domain-optical coherence tomography. Invest Ophthalmol Vis Sci. 2011; 52: 3901-3907

18. Chen X., Stojanovic A., Liu Y., et al, Postoperative changes in corneal epithelial and stromal thickness profiles after photorefractive keratectomy in treatment of myopia. J Refract Surg. 2015; 31 (7): 446-453.

19. Kanellopoulos A., Asimellis G. In vivo three-dimensional corneal epithelium imaging in normal eyes by anteriorsegment optical coherence tomography: A clinical reference study. Cornea. 2013; 32: 1493-1498.

20. Reinstein D., Archer T., Gobbe M. Change in epithelial thickness profile 24 hours and longitudinally for 1 year after myopic LASIK: Threedimensional display with Artemis very high-frequency digital ultrasound. $\boldsymbol{J}$ Refract Surg. 2012; 28: 195-201.

21. Hou J., Wang Y., Lei Y., et al, Corneal epithelial remodeling and its effect on corneal asphericity after transepithelial photorefractive keratectomy for myopia, J. of Ophthalmology. 2016; Article ID 8582362.

22. Moilanen J., Vesaluoma M., Müller L., et al. Long-Term Corneal Morphology after PRK by in vivo confocal microscopy. Investigative Ophthalmology \& Visual Science. March 2003; 44: 1064-1069. 